процесами та методами, хто тримає все відкритим для необмеженої перевірки і ревізії, культивує цей метод як звичку у своїх учнів. Люди, які навчені цього, ніколи не будуть панічно тікати, не поспішають вірити, можуть розглядати речі як можливі або вірогідні до певного ступеню, без визначеності і без болю, можуть чекати на докази і зважувати докази, можуть чинити опір навіть притаманним їм забобонам.

Упродовж XX-го століття, яке знаменувало собою бурхливий науково-технологічний прорив, наука далеко сягнула уперед завдяки глибшому розумінню довкілля, побудованого на постулатах критичного мислення, запропонованих науковцями від сивої давнини до сьогодення. Відомий американський науковець, засновник сучасної школи критичного мислення Едвард Глейзер запропонував таке визначення терміна «критичне мислення»: «здатність критично мислити, як передбачено в цій роботі, охоплює три складники: 1) психологічна готовність розглядати вдумливо проблеми і питання, що входять до спектру власного життєвого досвіду; 2) знання методів логічного дослідження й аргументації; 3) наявність певних навичок у застосуванні цих методів. Критичне мислення вимагає наполегливих зусиль для дослідження будь-якого переконання чи уявної форми знання у світлі доказів того, що його підтримує та подальших висновків, до яких воно тяжіє. Воно також вимагає здатності вирізняти проблеми, знаходити реальні засоби розв'язання цих проблем, збирати й розташовувати в певному порядку необхідну інформацію, розпізнавати неявні припущення і давати оцінку, розуміти і використовувати мову з точністю, ясністю і чіткістю, тлумачити дані, давати оцінку доказам і оцінювати аргументи, визнавати наявність (або відсутність) логічних взаємозв'язків між твердженнями, робити виправдані висновки i узагальнення, перевіряти висновки й узагальнення, яких ми дійшли, реконструювати свої моделі переконання на основі ширшого досвіду, і висловлювати точні судження про конкретні речі і якості в повсякденному житті» [2].

Світ постійно змінюється і кладе початок новим реаліям у сучасній дійсності. Науковці всього світу активно вивчають світовий досвід, накопичений за багатовікове існування людства. Так, основи критичного мислення активно популяризуються й українськими науковцями. 3-поміж палких прихильників критичного мислення в Україні варто виокремити О. Тягла. У своїй статті «Деякі особливості інтелектуальної активності людини «швидкого» світу» [3] він зосереджує увагу на нагальну потребу «переформатування» освіти. Даючи досить короткий, але глибокий аналіз сфери освіти, автор підтримує зміни векторності освіти 3 інформативної на інструментальну. Саме інструменти пізнання світу допоможуть виховати той інтелектуально-вольовий потенціал мільйонів, який стане запорукою швидкого розвитку України та її подальшої євроінтеграції.

Реалії сьогодення вимагають миттєвої реакції на ті зміни, які постійно відбуваються у соціумі. Отже, активне впровадження в навчальні програми критичного мислення дозволять нашій країні швидко подолати відставання і зайняти почесне місце серед найрозвиненіших країн не тільки Свропи, а й світу.

\title{
Література
}

1. California Teacher Preparation for Instruction in Critical Thinking : Research Findings and Policy Recommendations / Richard Paul, Linda Elder, and Ted Bartell ; State of California, California Commission on Teacher Credentialing, Sacramento. - March, 1997. 2. Glaser E. M. An Experiment in the Development of Critical Thinking / Edward M. Glaser. - Teacher's College, Columbia University, 1941. 3. Тягло О. В. Деякі особливості інтелектуальної активності людини «швидкого» світу / О. В. Тягло // Вісник ХНУ імені В. Н. Каразіна. Серія «Філософія. Філософські перипетії». - 2012. - № 992.

Олеся Мегем

\section{МОДЕРНІЗАЦІЯ ШКІЛЬНОЇ БІОЛОГІЧНОЇ ОСВІТИ В УКРАЇНІ У ДРУГІЙ ПОЛОВИНІ 60-х - СЕРЕДИНІ 80-х РОКІВ ХХ ст.}

Мегем О. М. Модернізація шкільної біологічної освіти в Україні у другій половині $60-\mathrm{x}-$ середині 80 -х років XX ст.

У статті шляхом здійснення аналізу стратегії руху суспільного середовища в досліджуваних хронологічних межах визначено провідні орієнтири розвитку шкільної 
біологічної освіти. Установлено характер впливу суспільно-політичних, соціально-економічних та ідеологічних чинників на формування змістово-методичних тенденцій.

Ключові слова: шкільна біологічна освіта, програма, якість навчання, аналіз, методичні ідеї.

Мегем О. М. Модернизация школьного биологического образования в Украине во второй половине 60-х - середине 80-х годов ХХ ст.

В статье на основе анализа стратегии движения общественной среды в исследованных хронологических рамках определены ведущие ориентиры развития школьного биологического образования. Установлен характер влияния общественно-политических, социально-экономических и идеологических факторов на формирование содержательно-методических тенденций.

Ключевые слова: школьное биологическое образование, программы, качество обучения, анализ, методические идеи.

Megem O. M. Modernization of school biology education in Ukraine in the second half of the 60 's-mid 80 -ies of the XX century.

On the basis of the analysis of movement strategies of the social environment in the studied chronological framework identifies the leading landmarks in the development of school biology education. The influence of socio-political, socio-economic and ideological factors on the formation of substantive and methodological trends.

Key words: school biology education, programs, quality of education, analysis, teaching ideas.

Важливого значення набуває нині, у час відродження української державності, пізнання історії шкільної біологічної освіти, адже вона невіддільна від загальних закономірностей розвитку i функціонування освіти (науки) як єдиного цілого. Сучасну освіту можна схарактеризувати як стратегічно не визначену, нестійку, із внутрішніми суперечностями, яка остаточно ще не склалась. У ній збереглись елементи радянської школи і водночас з'явилися нові тенденції у зв'язку з соціальною перебудовою держави, ознаками функціонування західної школи. Успіхи іiі докорінного реформування значною мірою залежать і від того, наскільки будуть використані національні й світові педагогічні надбання, здобутки майстрів-педагогів, раціонально поєднані класична спадщина і сучасні дослідження. Свідоме чи несвідоме ігнорування набутого досвіду збіднить педагогічну палітру національної системи освіти, ускладнить досягнення іiї стратегічних цілей.

Серед невеликої кількості досліджень, що стосуються проблеми історіографії шкільної біологічної освіти в Україні, слід виокремити праці Н. Міщук, І. Мороза, М. Скиби, А. Степанюк, які $є$ плідною спробою розкриття деяких аспектів розвитку шкільної біологічної освіти в Україні з позицій сьогодення. Але недостатньо дослідженою залишається проблема впливу суспільного середовища на розвиток шкільної біологічної освіти у другій половині $60-\mathrm{x}-$ середині 80 -х років XX ст.

Mета статmі: виявити загальні тенденції розвитку шкільної біологічної освіти в зазначених хронологічних межах; виокремити пріоритетні напрями її новаційного розвитку.

У другій половині 60-х - середині 80-х pp. XX ст. смерть Й. Сталіна відкрила новий цикл у радянській історії. Виснажливий, затратний, нераціональний метод правління $з$ допомогою терору i примусу не можна було використовувати безкінечно. Виникла необхідність послаблення жорсткого сталінського контролю. У суспільстві все більш контрастно прослідковувався новий шлях розвитку радянської держави з процесами десталінізації і часткової демократизації, що зумовило стрімкий розвиток науки, техніки, освіти. Освіта відійшла від системи номенклатури предметів лише за основами наук, було уведено інтегровані курси, факультативи. Відбулося часткове викремлення науково-педагогічних теорій: концепції розвивального навчання, індивідуалізації і диференціації навчально-виховного процесу, проблемного навчання та інших. Також здійснено трансформацію шкільної біологічної освіти на основі найважливіших досягнень біології та інших природничих наук, заборонених до цього часу як псевдонаукові. Починаючи з зазначеної фази розвитку суспільства, шкільна біологічна освіта дотримувалася вимог сучасності й будувалася на основі нових досягнень науки. Основна стратегія руху суспільного середовища зазначеного мегаперіоду - стрімкий розвиток науки, техніки, шкільної біологічної освіти під впливом десталінізації суспільства. 
У серпні 1964 р. ЦК КПРС та Рада Міністрів СРСР прийняли постанову «Про зміну терміну навчання в середніх загальноосвітніх трудових політехнічних школах з виробничим навчанням», якою передбачався перехід шкіл знову на 10-річний термін навчання. Однак, у постанові підкреслювалось, що школа не повертається до старої десятирічки, а продовжує розвиватись як трудова, політехнічна з виробничим навчанням [5, с. 185-186]. Міністерство освіти СРСР і міністерства народної освіти союзних республік повинні були внести відповідні зміни до навчальних планів і програм загальноосвітніх шкіл. У 1964 р., після жовтневого Пленуму ЦК КПРС, було відновлено в правах заборонені напрями у біології: істинне дарвінівське учення про еволюцію органічного світу, основи класичної генетики, молекулярної біології. У 1965 р. Т. Лисенка було знято з посади директора Інституту загальної генетики АН СРСР.

У 1965 р. розпочато роботу зі створення нової програми 3 «Загальної біології». У березні 1966 року МО УРСР видало постанову «Про введення курсу загальної біології в 1966/67 навчальному році в X класах». У цій постанові наголошувалось на проведенні двотижневих курсів для вчителів, що викладатимуть курс «Загальна біологія» в Х класах; наказувалося забезпечити виготовлення діафільмів «Генетика і селекція», «Клітина, іiї будова і функції» [12, c. 17]. Нова програма передбачала ознайомлення учнів 3 досягненнями біологічної науки, біогеоценологією, вченням про біосферу.

У листопаді 1966 р. ЦК КПРС та Рада Міністрів СРСР прийняли постанову «Про заходи дальшого поліпшення роботи середньої загальноосвітньої школи» [13], у якій підкреслювалось, що зміст освіти треба структурувати відповідно до вимог розвитку науки, культури і техніки; забезпечити наступність у вивченні основ наук. Для поглиблення знань із природничих та інших наук школам надавалось право проводити, починаючи 37 класів, факультативні заняття.

Упродовж 1967-1975 pр. здійснено планомірний перехід середніх шкіл на нові навчальні плани і програми. Програми відрізнялися від попередніх напрямом наукового викладу, а не лише уведенням нового матеріалу за рахунок скорочення й виключення інших відомостей, ураховувалась роль біології в навчанні й вихованні підростаючого покоління. Грунтовної переробки зазнав курс «Загальна біологія», у якому питання спадковості й мінливості трактувалися з позицій молекулярної біології. У програмі орієнтація робилася і на реалізацію політехнічного принципу, який би забезпечив розуміння учнями біологічних основ не лише з сільського господарства, але й 3 інших галузей народного господарства, а також з охорони здоров'я.

Уведення нових програм здійснювалося поступово. У 1968/1969 н. р. запроваджено програми 3 курсів: «Ботаніка» (V кл.), «Фізіологія людини» (VIII кл.) (попередня назва «Анатомія, фізіологія і гігієна людини»). У 1969/1970 н. р. - 3 «Ботаніки» (VI кл.), відновлено назву курсу «Анатомія, фізіологія і гігієна людини» (VIII кл.). Упродовж 1970-1975 н. p. - із «Зоології» (VI-VII кл.) та вдосконалено програми 3 «Ботаніки» (V-VI кл.), «Анатомії, фізіології і гігієни людини» (VIII кл.). Нову програму з «Загальної біології» було введено у 1966/1967 н. р. Вивчення курсу планувалося у Х класі.

У 1970/1971 н. р. за рішенням Колегії Міністерства освіти СРСР вивчення курсу «Загальна біологія» планувалося упродовж 2 років - у IX та Х класах. У 1970/1971 н. р. нові програми 3 «Загальної біології» було введено у школах з російською мовою навчання, а $з$ 1971/1972 н. р. у школах республік.

У 1968 році було опубліковано «Примірну програму для самоосвіти вчителів біології», яка складалася з таких розділів: 1) науково-теоретична підготовка; 2) актуальні питання дидактики; 3) теорія і практика виховної роботи в школі; 4) актуальні питання методики викладання біології [11].

Починаючи з 1965 р. на допомогу вчителям біології регулярно видавалися республіканські методичні збірники: «Викладання біології в школі» та «Методика викладання біологічних наук». Було опубліковано програми гуртків для старшокласників (юних біоніків, генетиків та селекціонерів, мікробіологів) [3]. Республіканською станцією юних натуралістів створено посібники 3 питань організації дослідницької та натуралістичної роботи школярів. Опубліковано книги для читання з біології, видано навчальні таблиці, кінофільми, діафільми та інші дидактичні матеріали. Було сформовано систему методичної роботи 3 педагогічними кадрами. Працювали методичні об'єднання, семінари, семінари-практикуми, школи передового педагогічного досвіду, опорні школи, народні університети науково-педагогічних знань. 
У другій половині 60 -х років ХХ ст. відбулося оформлення цілої низки педагогічних ідей і теорій, пов'язаних із дослідженням шляхів ефективного навчання учнів. У ці роки у школах здійснено перехід від методів подання готових знань до методики організації самостійної пізнавальної діяльності школярів.

Проте результати інспекторських перевірок, аналіз контрольних робіт учнів за 1968 1973 рр. показали, що поряд із певними успіхами у методиці навчання біології мали місце серйозні недоліки в системі роботи вчителів, зокрема, недостатнє володіння теоретичним матеріалом 3 основ біології; недостатнє застосування активних методів навчання та проблемного підходу; порушення політехнічного принципу навчання біології; невиконання передбаченого програмою мінімуму лабораторних робіт та екскурсій; недооцінювання спостережень і біологічного експерименту; невідповідність матеріального забезпечення вимогам нових програм [4].

Задля підвищення якості навчання у 1971/1972 н. р. було уведено екзамени з біології у IX $\mathrm{X}$ класах [2], запроваджено проведення шкільних, районних, обласних, республіканських біологічних олімпіад [15].

В умовах всебічної допомоги в роботі з трудового виховання та професійної орієнтації учнів для підвищення якості навчального процесу в школі, виявлення кращих прикладів дослідницької і масової натуралістичної роботи з біології та сільського господарства у 1971 р. було оголошено республіканський конкурс на кращу дослідницьку роботу з біології та сільського господарства у восьмирічних i середніх школах та позашкільних закладах Української РСР [8].

У 70-ті роки ХХ ст., у зв'язку з прийняттям постанови ЦК КПРС «Про завершення переходу до загальної середньої освіти молоді і подальший розвиток загальноосвітньої школи Української РСР» (1972р.), розпочалося широке впровадження в практику школи кабінетної системи. Так, у 1975 році Колегією МО УРСР були затверджені положення про навчальний кабінет біології середньої загальноосвітньої школи [7] та про факультативні заняття в загальноосвітній школі Української РСР [10].

У зв'язку із загостренням на початку 70 -х років $\mathrm{XX}$ ст. екологічної ситуації особливим соціальним і літературним явищем стала тема охорони природи. Наказ МО УРСР «Про посилення охорони природи і поліпшення використання природних ресурсів» (1973 р.) зобов'язував учителів під час викладання природничих дисциплін у школах звертати особливу увагу на питання охорони природного середовища, виховувати прагнення в учнів до активної участі в роботі з охорони довкілля, відтворення і раціонального використання природних ресурсів країни [14].

У 1976 р. Міністерство освіти СРСР на засіданні колегії прийняло рішення «Про стан і заходи покращення викладання загальної біології в загальноосвітній школі (IX - X класи)» [17, c. 6]. Колегія ухвалила, що курс загальної біології за новою програмою в цілому відповідає навчально-виховним завданням школи, але мають місце й істотні недоліки, особливо в реалізації практичної частини програми. Задля покращення навчання біології, використання виховних можливостей предмета Міністерство освіти СРСР затвердило план конкретних заходів, спрямований на подальше підвищення якості навчання шкільній біології. Рекомендувалось посилити інспекторський контроль за станом викладання біології і якості знань учнів, проведенням позакласної роботи, особливо з охорони природи, завершенням організації в усіх школах кабінетів біології, навчально-дослідних ділянок. Особлива увага зверталась на узагальнення передового досвіду вчителів та заходи щодо впровадження його в школи.

Чергові завдання постали перед шкільною біологічною освітою у зв'язку 3 постановою Центрального Комітету КПРС і Ради Міністрів СРСР від 22 грудня 1977 року «Про подальше вдосконалення навчання, виховання учнів загальноосвітніх шкіл і підготовки їх до праці» [1, c. 6]. У постанові зверталась увага на підвищення теоретичного рівня наукових знань та використання новітніх методів навчання; покращення професійної орієнтації учнів та трудового виховання школярів. Наголошувалося на посиленні загальнобіологічної та політехнічної спрямованості курсів ботаніки, зоології, анатомії, фізіології і гігієни людини, внутрішньопредметних та міжпредметних зв'язків.

На початку 1978 р. були опубліковані корективи до навчальних програм із біології, зокрема, поданий перелік програмового матеріалу, який знімався 3 вивчення. Вивільнений 
навчальний час рекомендувалось використовувати на вивчення окремих тем курсів, проведення вступних, узагальнювально-повторювальних та підсумкових занять, на виконання лабораторно-практичних робіт. Наголошувалось, що важливим резервом подолання перевантаження учнів залишається підвищення ефективності уроку.

У 1978 р. на обговорення було винесено проект програми з біології для загальноосвітніх шкіл. Перебудова програми здійснювалась за такими напрямами: підвищення наукового рівня біології, скорочення другорядного і складного матеріалу; виховання в учнів відповідальності за збереження природи; розвиток у них умінь і навичок самостійного поповнення знань; активізація пізнавальної діяльності учнів; посилення ідейно-політичного потенціалу уроків; забезпечення трудової, політехнічної спрямованості біології задля кращої підготовки учнівської молоді до свідомого вибору професії.

Діяльність методистів у ці роки було спрямовано на розроблення екологічного виховання, проблемного навчання, шляхів розвитку мислення учнів, використання міжпредметних зв'язків, політехнічної підготовки; індивідуалізації навчання.

Перевірка стану навчання і якості знань учнів із біології у школах УРСР у 1983 р. показала, що учні засвоюють фактичний матеріал без достатнього усвідомлення внутрішнього змісту біологічного явища, не вміють виокремлювати головне, встановлювати зв'язки наукових досягнень із практикою; спостерігався низький рівень засвоєння учнями окремих біологічних і політехнічних понять, сформованості практичних умінь та навичок [6].

У січні 1984 р. колегія МО УРСР ухвалила рішення «Про стан викладання за удосконаленими програмами, якість знань, умінь і практичних навичок учнів 3 біології у загальноосвітніх школах республіки» [16], у якому зазначалися такі заходи щодо подальшого удосконалення навчання біології в загальноосвітніх школах: забезпечити високий науковий рівень викладання, міцність знань і практичних навичок учнів; посилити роботу з підготовки учнів до праці в сільськогосподарському виробництві, широко використовуючи можливості природознавства і біології, позакласних заходів, дослідницької роботи на навчально-дослідних ділянках, у теплицях i виробничих бригадах; удосконалити роботу шкіл і класів із поглибленим теоретичним і практичним вивченням біології, факультативних занять із біологічних курсів i охорони природи; підготувати і видати програму для шкіл із поглибленим вивченням біології; забезпечити організацію шкільних або міжшкільних навчально-дослідних ділянок для всіх міських і сільських шкіл; розробити заходи щодо повного забезпечення шкільних кабінетів біології обладнанням; проаналізувати й обговорити ефективність методичної роботи і курсової перепідготовки вчителів біології [16, с. 4-7].

Задля масового залучення школярів до дослідницької роботи з біології й основ сільського та лісового господарства упродовж 1984-1990 рр. Міністерством освіти УРСР, ЦК ВЛКСМ України, Міністерством сільського господарства УРСР, Академією наук УРСР та Республіканською станцією юних натуралістів було оголошено конкурс на кращу дослідницьку роботу з біології і сільського господарства у восьмирічних та середніх школах і позашкільних закладах Української РСР [9].

Здійснений аналіз динаміки розвитку шкільної біологічної освіти 3 другої половини 60 -х до середини 80-х pp. ХХ ст. дозволив стверджувати, що в зазначений проміжок часу домінували такі тенденції розвитку шкільної біологічної освіти: процеси десталінізації суспільства; науково-технічний прогрес; зростання ролі освіти в усіх сферах життя суспільства; творча діяльність педагогів-новаторів; трансформування шкільної біологічної освіти на основі найважливіших досягнень біологічної науки; модернізація і покращення організації навчальновиховного процесу в школі; впровадження у практику школи кабінетної системи; підвищення ролі виховуючого навчання; уведення факультативних занять; запровадження шкільних, районних, обласних, республіканських олімпіад з біології. Виокремлені тенденції допоможуть подолати кризу, що виникає як наслідок суперечностей між доцентровими (середовище система) і відцентровими (система - середовище) силами, які діють у межах певної соціальноекономічної епохи. Вони є методологічним підгрунтям для розроблення мобільної системи шкільної біологічної освіти, яка буде швидко реагувати на зміни детермінуючих чинників суспільного середовища. 


\section{Література}

1. В Центральном Комитете КПРСС и Совете Министров СССР // Биология в школе. - 1978. - № 2. C. 6-11. 2. Екзаменаційні білети з біології на атестат за середню освіту (IX - X класів масових шкіл та X - XI класів вечірніх (змінних) і заочних шкіл) на 1971/72 навчальний рік // Збірник наказів та інструкцій Міністерства освіти Української РСР. - 1971. - № 18. - С. 5-8. 3. Коптєва Е. М. Вивчення біології за новими програмами / Е. М. Коптева // Радянська школа. - 1970. - № 6 - С. 43-48. 4. Освоение новых программ, совершенствование преподавания биологии - неотложная задача учителя // Биология в школе. - 1969. - № 4. - С. 3-5. 5. Очерки истории школы и педагогической мысли народов СССР (1961 -1986 гг.): [отв. ред. Паначин Ф. Г. и др.]. - М. : Педагогика, 1987. - 416 с. 6. Політехнічне навчання в курсі біології в середній школі: [відпр. ред. Ф. Л. Лесик]. - К. : Радянська школа, 1957. - 135 с. 7. Положення про навчальний кабінет біології середньої загальноосвітньої школи: Затверджено колегією Міністерства освіти УРСР 6 серпня 1975 року // Збірник наказів та інструкцій Міністерства освіти Української РСР. - 1975. - № 20. - С. 14-23. 8. Положення про республіканський конкурс на кращу дослідницьку роботу з біології та сільського господарства у восьмирічних і середніх школах та позашкільних закладах Української РСР // Збірник наказів та інструкцій Міністерства освіти Української РСР. - 1971. - № 9-10. - С. 24-27. 9. Положення про республіканський конкурс на кращу дослідницьку роботу з біології та сільського господарства в загальноосвітніх школах і позашкільних закладах Української РСР: Загальні положення // Збірник наказів та інструкцій Міністерства освіти Української РСР. - 1984. - №7. - С. 16-21. 10. Положення про факультативні заняття в загальноосвітній школі Української РСР: Затверджено Міністр. освіти УРСР О. М. Маринич 17 березня 1975 р. // Збірник наказів та інструкцій Міністерства освіти Української РСР. - 1975. - № 9. - С. 15-17. 11. Примірна програма для самоосвіти вчителів біології // Збірник наказів та інструкцій Міністерства освіти Української РСР. - 1968. - № 23. - С. 3-22. 12. Про введення курсу загальної біології в 1966/67 навчальному році в Х класах: наказ № 68 від 12 березня 1966 р. // Збірник наказів та інструкцій Міністерства освіти Української РСР. - 1966. - № 7. - С. 17-20. 13. Про заходи дальшого поліпшення роботи середньої загальноосвітньої школи // Збірник наказів та інструкцій Міністерства освіти Української РСР. - 1966. - № 23. - С. 2-12. 14. Про посилення охорони природи і поліпшення використання природних ресурсів // Збірник наказів та інструкцій Міністерства освіти Української РСР. - 1973. - № 6. - С. 25-26. 15. Про проведення в 1971/72 навчальному році олімпіад юних математиків, фізиків, хіміків, біологів, географів-краєзнавців, істориків, літераторів та знавців іноземних мов: наказ № 339/802 від 23 листопада 1971 р. // Збірник наказів та інструкцій Міністерства освіти Української РСР. - 1972. - № 1. - С. 6-10. 16. Про стан викладання за удосконаленими програмами, якість знань, умінь і практичних навичок учнів 3 біології у загальноосвітніх школах республіки: Рішення колегії Міністерства освіти УРСР від 25.01.1984 р. // Збірник наказів та інструкцій Міністерства освіти Української РСР. - 1984. - № 6. - С. 3-20. 17. Румянцева М. Н. Повышать эффективность и качество биологического образования / М. Н. Румянцева, А. Н. Мягкова, Б. Д. Комиссаров // Биология в школе. - 1976. - № 5. - С. 3-8.

\section{ЕКОЛОГІЗАЦІЯ ШКІЛЬНОГО КУРСУ ГЕОГРАФІЇ В 90-ТІ РОКИ}

Оржаховська А. Г. Екологізації шкільного курсу географії в 90-ті роки.

У статті висвітлено зміст поняття «екологізація географії», розглянуто роль педагогічної преси в еколого-виховному процесі, подано приклади впровадження екологічних знань у різних навчальних закладах і залучення школярів до розв'язання проблем навколишнього середовища.

Ключові слова: екологічна освіта та виховання, екологічна відповідальність, екологізація географії, педагогічна преса.

Оржаховская А. Г. Экологизация школьного курса географии в 90-е годы.

В статье раскрывается понятие «экологизация географии», рассматривается роль педагогической прессы в эколого-воспитательном процессе, приведены примеры внедрения экологических знаний в различных учебных заведениях и привлечение школьников к решению проблем окружающей среды.

Ключевые слова: экологическое образование и воспитание, экологическая ответственность, экологизация географии, педагогическая пресса. 